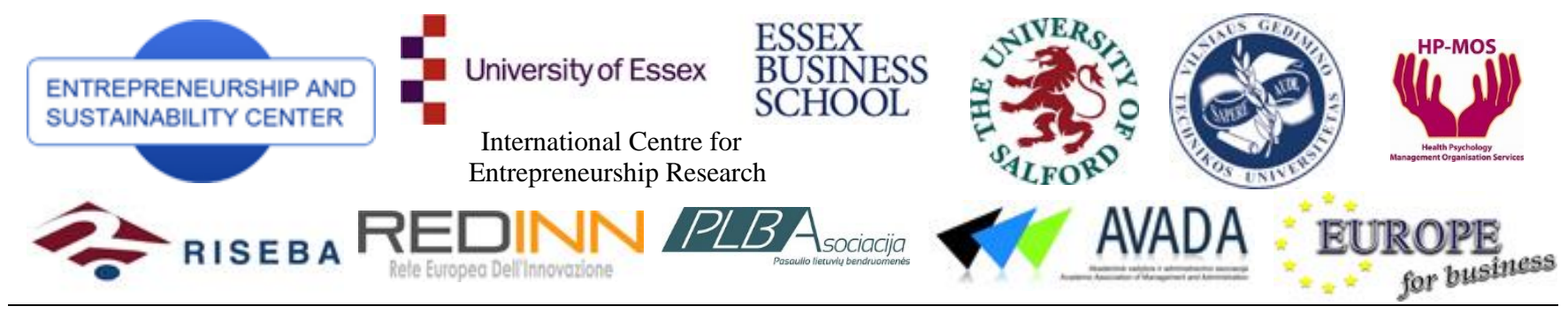

ENTREPRENEURSHIP AND SUSTAINABILITY ISSUES

ISSN 2345-0282 (online) http://jssidoi.org/jesi/

\title{
CAMELS+T APPROACH FOR BANKS' SOUNDNESS ASSESSMENT: EVIDENCE FROM THE BALTICS
}

\author{
Daiva Jurevičienè1, Viktorija Skvarciany² \\ 1,2 Vilnius Gediminas Technical University, Sauletekio ave. 11, LT-10223 Vilnius, Lithuania \\ E-mails: ${ }^{1}$ daiva.jureviciene@vgtu.lt; ${ }^{2}$ viktorija.skvarciany@vgtu.lt
}

Received 20 June 2016; accepted 15 September 2016

\begin{abstract}
The findings of the research contribute towards commercial banks' soundness assessment. The current study focuses on the importance of customers' trust for banks' soundness and the expanded CAMELS+T model was suggested where "T" stands for customer trust. For testing CAMELS+T model expert evaluation method was used Pairwise comparison method was used for factors' ranking. The outcomes of the experts' pairwise comparison were generated using analytic hierarchy process (AHP) based on classical and balanced scales and fuzzy analytic hierarchy process (FAHP) technique. The model was tested in the Baltic countries. Three forms of banking were analysed: traditional banking, internet banking and mobile banking in the current research. The results of the study showed that customer trust is one of the vital factors positively influencing the soundness of commercial banks. Therefore, the results contribute to the studies relating bank performance, as it confirms that trust is a powerful tool in commercial banks' soundness building process. The results of the research are useful for commercial banks' soundness' assessment as soundness is considered the factor that is necessary not only for customer retention but also for customer acquisition. The findings have implications on the development of the strategy and the policy of commercial banks. Moreover, the results are valuable for investors as the soundness of commercial bank is the criterion investors should take into consideration while choosing a bank they are going to work with.
\end{abstract}

Keywords: trust, soundness, traditional, internet, mobile banking, CAMELS+T model, analytic hierarchy process (AHP), fuzzy analytic hierarchy process (AHP)

Reference to this paper should be made as follows: Jurevičienè, D.; Skvarciany, V. 2016. Camels+t approach for banks' assessment: evidence from the Baltics, Entrepreneurship and Sustainability Issues 4(2): 159-173. DOI: http://dx.doi.org/10.9770/jesi.2016.4.2(4)

JEL Classifications: G21, C51

\section{Introduction}

Scientists from various countries widely analyse the concept of financial sector soundness, as soundness is one of the most important factors, promoting sustainable development of banking sector itself and important factor of sustainable development of countries (Al-Khouri, Arouri, 2016; Motelle, Biekpe, 2014; Lui, 2013; Dubauskas, 
2012; Kaźmierczyk, 2012; Milvydienė, 2012; Lankauskienė, Tvaronavičienė 2012; Stasytytė 2015; Fuschi, Tvaronavičienė 2014; Kalyugina et al., 2015; Korauš et al., 2016).

Overall financial soundness depends on banks' soundness (Podviezko, Ginevičius, 2010; Warjiyo, 2016, Tamulevičienè, 2016). Low level of banks' soundness weakens entire banking system and makes the country more exposed to financial crises (Park, 2012). The soundness of banking sector is the most important principle of global financial soundness (Dima et al., 2014) and it is very important to avoid such crises as the last one in 2008. Thus, the soundness of banking sector is the basis of overall financial system consistency as banks play the most important role in the money creation process, payment systems, investments financing and development of economy (Hussein, 2010). As it was already mentioned above, the soundness of banks is necessary condition for sustainable economic growth (Ginevicius, Podviezko, 2013; Karanovic, Karanovic, 2015; Menicucci, Paolucci, 2016) and overall economic stability (Fernández et al., 2016; Dudzevičiūtė et al. 2014).

Many scientists use CAMELS model for evaluation of banks' soundness, which was proposed in 1996 (Sahajwala, Van den Bergh, 2000). For more than twenty years, economic and political situations in countries have been changing, information technologies have been evolving and electronic banking has gained popularity. Due to the above-mentioned changes, there is a necessity to modify the methodology in assessing commercial banks' soundness, to revise soundness determinants.

One such factor is the private consumer confidence in commercial banks that is being examined by a number of scientists. Furthermore, researchers exploring the confidence of commercial banks agree that this is one of the most important factors in determining the success of the banking activities.

Therefore, the goal of the current paper is to explore whether there is an interface between customers' trust and commercial banks' soundness. Based on the literature analysis of main factors of banks' soundness, the following hypothesis was stated:

\section{H: Trust is one of the vital factors influencing commercial banks' soundness.}

Three forms of banking were analysed: traditional banking, internet banking and mobile banking in the current research. Expert evaluation method was used for data collection. Results were analysed using analytical hierarchy process (AHP) using classical and balanced scales and AHP based on fuzzy logic. The current research contributes to scientific literature in the field of banks' soundness assessment methods. The results of the study showed that there is a need to modify CAMELS model to CAMELS+T model, where "T" stands for "trust".

\section{Interface between trust and soundness in banking}

Scientists dealing with commercial banking sector agree that trust is a determinant of successful banking operations. Trust promotes cooperation between the bank and the customer, it allows the bank to maintain / gain competitive advantage. Increasing diversity of services provided by commercial banking requires customer trust, which becomes a factor encouraging customer to make a decision regarding choosing the bank. Thus, trust is a crucial factor, ensuring not only the smooth functioning of the banking activities, but also the soundness and development of its activities. In addition, trust provides high-quality social relationships with the banking service users and partners. Hence, examination of consumer trust, as one of the factors of soundness, will help to understand the form and strength of the impact of trust on soundness as well as to strengthen these success factors ensuring the activities of banks.

In the post-crisis period, scientists began to emphasize the link between customer trust and soundness of commercial banks. For instance, according to Gao et al. (2016) the high level of investors' trust directly influences the soundness of the financial system. Actually, commercial banks are the major part of the financial system, hence it could be 
concluded that there is a positive correlation between the customer trust and the soundness of commercial banks. Sokolova, Tishina (2015) say that there is a close relation between the banks' business soundness and trust in commercial banks. In fact, the greater the level of customer trust the higher the level of the soundness of commercial banks (Fungáčová, Hasan, 2016). Loss of trust is so important that there is a problem for the financial soundness as well (Nicolaci, 2014). Undermining trust impinges negatively upon the soundness of financial system (Minto, 2016), in particular upon the soundness of commercial banks. Carretta et al. (2015) highlight indirect correlation between trust and soundness. The authors emphasize collectivism to be positively linked to the soundness of commercial banks while one of the collectivism elements is trust (Carretta et al., 2015).

According to the interface between trust and soundness provided by scientists it is proposed to modify the existing soundness assessing CAMELS model - adding to it the trust factor. It is offered to name CAMELS+T the expanded model. Fig. 1 shows graphic representation of the model.

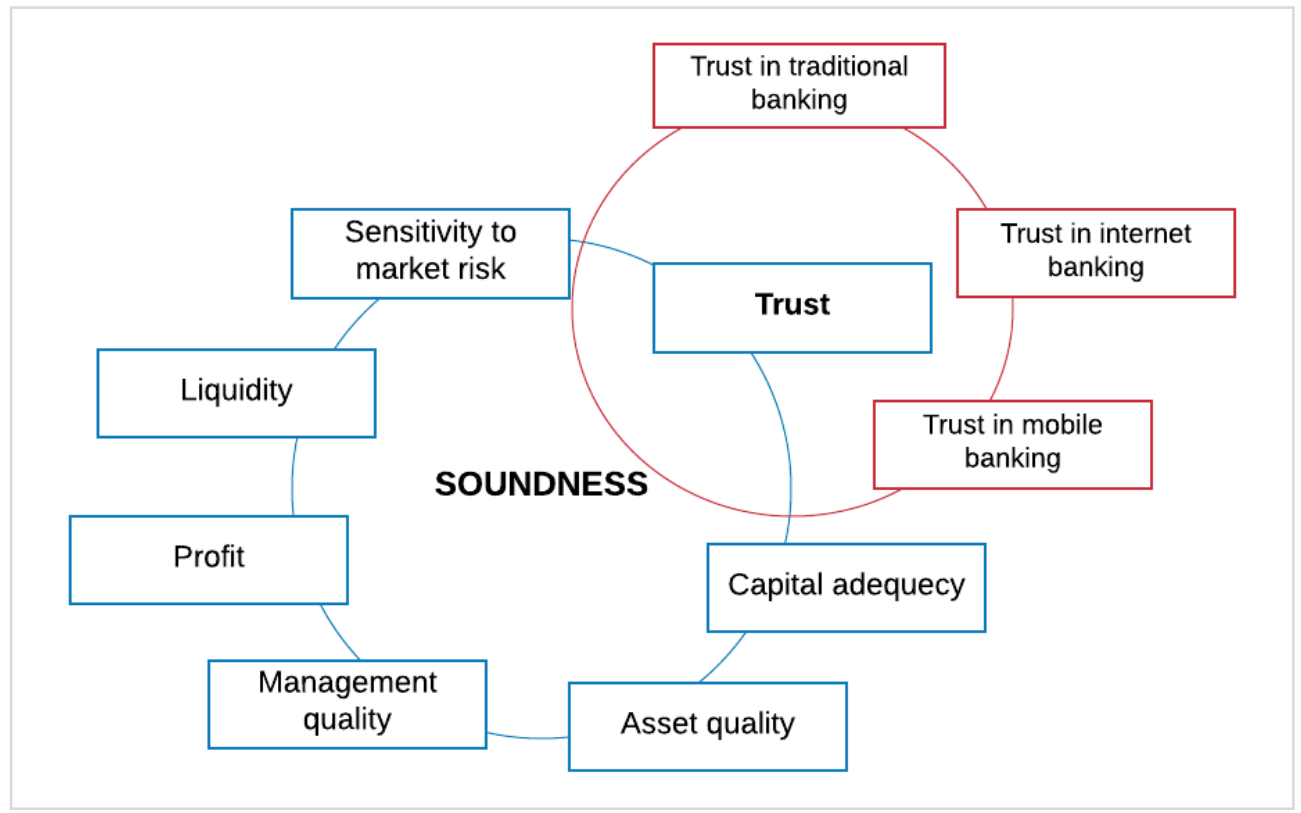

Fig.1. Graphic Representation of CAMELS+T Model

Source: designed by authors

It can be seen in Fig. 1, that the proposed CAMELS + T model is a seven-factor model including trust. Trust is depicted as union of trusts in three banking forms. In fact, many researches study the theoretical aspects of the relationship between trust and soundness of banks, but there is a lack of empirical studies analysing the influence of trust on the soundness of commercial banks. For this reason, this article investigates the impact of consumer trust on the soundness of commercial banks empirically and studies the generated results that can be adapted to the development of commercial banking business.

The World Economic Forum announces commercial banks activities soundness' data annually (Schwab, 20082016). Experts assess banks' soundness using seven-point Likert scale. The diagram of banks soundness values for Lithuania, Latvia and Estonia is presented in 
Fig. 1 for the period 2008-2016.

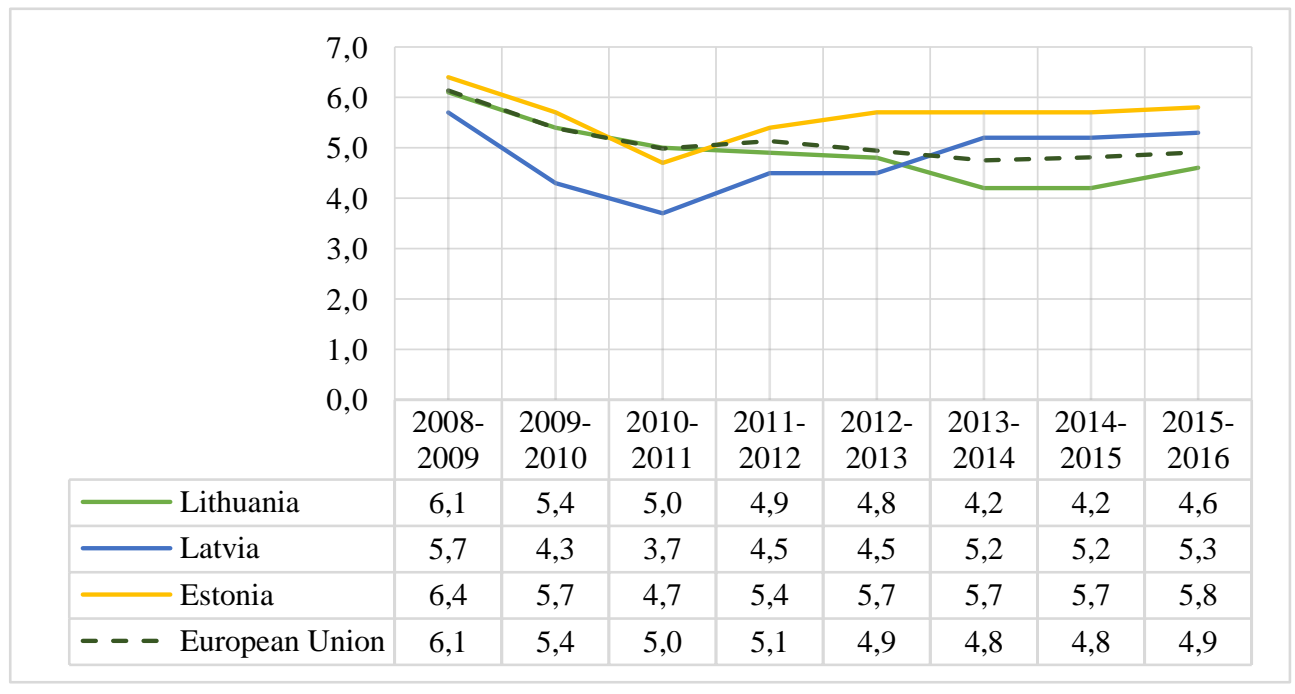

Fig. 1. Analysis of Commercial Banks' Soundness Situation in the Baltic Countries

Source: designed by authors based on Schwab (2008-2016)

According to Fig. 2, Latvia's and Estonia's banks' soundness assessment is higher than the European Union's average in recent years. However, assessment of soundness in Lithuania's banks is 0.3 points lower than the EU average in 2015-2016. What is more, neither the EU banks soundness' average assessment nor Baltic States' banks' soundness assessment has reached the level before the global financial crisis. One of the factors that could support the high level of bank soundness is trust. To understand the significance of trust level it is necessary to clarify the weight of trust factor in soundness building process.

\section{Methodology}

The expert evaluation method was chosen for data collecting. The number of respondents in expert evaluation was picked out according to Libby and Blashfield (1978) recommendations. According to Libby and Blashfield (1978) the reliability of the results obtained by the group of five experts exceeds 75 percent threshold. Pairwise comparison method used for ranking. According to this technique, each alternative matches one-on-one with each of the other 
alternatives what gives a more precise rating. The outcomes of the experts' pairwise comparison were generated using analytic hierarchy process (AHP) based on classical and balanced scales and fuzzy analytic hierarchy process (FAHP).

\subsection{Analytic hierarchy process}

Analytic hierarchy process is multidimensional method that could be applied when it is necessary to take into account several criterion for decision making (Zolfani, Antucheviciene, 2012).

AHP method, using classical and balances scales, was selected to assess CAMELS+T model dimensions influence on banks' soundness. Analytic hierarchy process is a multicriterial model designed for decision-making. There are several assessment criterion that ought to be taken into account (Zolfani, Antucheviciene, 2012).

According to the method experts compare alternatives $\left\{\theta_{1}, \ldots, \theta_{n}\right\}$ with each other by filling pairwise comparison matrices (see (1)).

where: $a_{i j}=\frac{\omega_{i}}{\omega_{j}}, \forall i, j=1,2, \ldots, n$,

$$
\mathrm{A}=\left(a_{i j}\right)_{n \times n}
$$

$$
\begin{aligned}
& \omega_{n}(n=1,2, \ldots n)-\text { priority vector, } \\
& a_{i j}=\frac{1}{a_{j i}}, \forall i, j=1,2, \ldots, n .
\end{aligned}
$$

For completing individual comparison matrices experts were suggested to use nine-point scale introduced by Saaty (Saaty, 1980) (see Table 1). Every expert had to evaluate $(n(n-1) / 2)$ pairs $(n$-number of alternatives).

Table 1. Scales of Relative Importance

\begin{tabular}{|c|l|}
\hline Estimation & \multicolumn{1}{c|}{ Linguistic variables } \\
\hline 1 & Equal importance \\
\hline 3 & Moderate importance \\
\hline 5 & Strong importance \\
\hline 7 & Very strong or demonstrated importance \\
\hline 9 & Extreme importance \\
\hline $2,4,6,8$ & Intermediate values \\
\hline $\begin{array}{c}\text { Reciprocals } \\
\text { to above }\end{array}$ & $\begin{array}{l}\text { If factor } i \text { has one of the above numbers assigned to } \\
\text { it when compared to factor } j, \text { then } j \text { has reciprocal } \\
\text { value when compared with } i\end{array}$ \\
\hline
\end{tabular}

$$
\text { Source: Saaty (1988) }
$$

However, the scale presented in Table 1 is not the only used for pairwise comparison. For instance, Salo, Hamalainen (1997) proposed balanced assessment scale. Linear and balanced scales' characteristics are presented in Table 2.

Table 2. AHP Scales Used in the Survey

\begin{tabular}{|l|c|c|l|}
\hline \multicolumn{1}{|c|}{ Type of scale } & Mathematical expression & Parameters & Approximate scale values \\
\hline Linear (Saaty, 1977) & $s=x$ & $x=\{1,2, \ldots, 9\}$ & $1 ; 2 ; 3 ; 4 ; 5 ; 6 ; 7 ; 8 ; 9$ \\
\hline $\begin{array}{l}\text { Balances (Salo \& } \\
\text { Hamalainen, 1997) }\end{array}$ & $s=\frac{w}{1-w}$ & $w=\{0,5 ; 0,55 ; 0,6 ; \ldots ; 9\}$ & $\begin{array}{l}1 ; 1,22 ; 1,5 ; 1,86 ; 2,33 ; 3 ; 4 ; \\
5,67 ; 9\end{array}$ \\
\hline
\end{tabular}


As shown in Table 2, different scientists offer different numeric scales to the same linguistic scales given in Table 1. The choice of the best scale is still debatable. For example, Goepel (2013) offers to use balanced scale along with the classical (linear) scale as using balance scale reduces inconsistency in experts' evaluations.

Salo, Hämäläinen (1997) claim that their proposed balanced scale improves the sensitivity of relative scales of AHP. Scientists offer natural number scale (from 1 to 9) providing the weights of the factors that are not equally distributed, which leads to two factors, placed next to each other, reducing sensitivity of comparison (Franek, Kresta, 2014). In other words, local weights are evenly distributed through the global weight range using balanced scale. However, the scientists claim that classical scale should be used by default and balanced scale could be additional one if there is a necessity to reach higher level of consistency (Franek, Kresta, 2014).

After experts complete pairwise comparison of the factors, all the assessments have to be written in standardised matrix form and arithmetic mean of each line is calculated. In this way, the main factor is identified. However, if the level of inconsistency is higher than the set limit, the matrix had to be modified into consistent one as consistency of the matrices shows whether experts' factors evaluations were logical and reliable. Pairwise comparison matrix is considered as consistent if $a_{i k}=a_{i j} a_{j k}, \forall i, j, k$. In other words, there is such priority vector $\mathrm{w}=\left(\omega_{1}, \ldots, \omega_{n}\right)$ that $a_{i j}=\omega_{i} / \omega_{j}, \forall i, j$. Analytic hierarchy process is the method that evaluates the consistency of each individual expert assessment within Consistency Index (CI) (Saaty, 2012). To determine consistency index an eigenvalue of pairwise comparison matrix is calculated (see (2)).

$$
\lambda_{\max }=\sum_{j=1}^{n} \frac{(A \cdot v)_{j}}{n \cdot v_{j}}
$$

where: $\lambda_{\max }-$ the largest eigenvalue of matrix $\mathrm{A}$,

$n$ - number of independent rows in the matrix,

$v_{j}$ - eigenvalue of the matrix.

If experts' pairwise comparison matrix $\mathrm{A}$ is consistent, $\lambda_{\max }=n$. If there are minor $a_{i j}$ changes and matrix $\mathrm{A}$ does not satisfy consistency condition, then the $\lambda_{\max }$ value is close to $n$. After the value of $\lambda_{\max }$ is computed, consistency index $C I$ could be calculated (see (3)).

$$
\begin{aligned}
& \text { where: } C I-\text { consistency index, } \\
& n \text {-number of alternatives. }
\end{aligned}
$$$$
C I=\frac{\lambda_{\max }-n}{n-1}
$$

For the purpose of consistency index assessment it was compared to Random Index $(R I)$ and Consistency Ration (CR) was computed (see (4)).

where: $C R$ - consistency ratio,

$$
C R=\frac{C I}{R I}
$$

$R I$-random index.

The values of consistency ratio depend on matrix order $m$. They are presented in Table 1 .

Table 1. Values of Random Index $(R I)$

\begin{tabular}{|c|c|c|c|c|c|c|c|c|c|c|}
\hline$n$ & 1 & 2 & 3 & 4 & 5 & 6 & 7 & 8 & 9 & 10 \\
\hline$R I$ & 0 & 0 & 0,58 & 0,9 & 1,12 & 1,24 & 1,32 & 1,41 & 1,45 & 1,49 \\
\hline
\end{tabular}


AHP method is considered as appropriate if $C R \in[0 ; 0,2)$ (Aksenov et al., 2014). If the matrix is inconsistent, it is modified by the method proposed by (Saaty, 2012). Obata et al. (1999) called the method Method-S. The steps of the method are as follows (Davoodi, 2009; Obata et al., 1999):

i) determining the priority weight vector $\omega=\left(\omega_{i}\right)$ by the eigenvector method;

ii) comparison of each value $a_{i j}$ with the corresponding ratio of weights $\omega_{i} / \omega_{j}$;

iii) identification of the most different element as inconsistent, and $a_{i j}$ replacement with $\omega_{i} / \omega_{j}$;

iv) estimation of the priority weights from the modified matrix.

For experts' pairwise comparison matrices that fulfil the consistency condition $(\mathrm{CR}<0,2)$, the aggregated experts' assessment is calculated. Aggregated experts' assessment is calculated using geometric mean (see (5)) (Kostin, 2014).

$$
a_{i j}^{A}=\sqrt[n]{a_{i j}^{1} \times a_{i j}^{2} \times \ldots \times a_{i j}^{n}}
$$

where: $a_{i j}^{A}$ - assessment of aggregated element that belongs to $i$ row and $j$ column.

$n$-number of pairwise comparison matrices composed by one expert.

Consistency ratio calculation procedure is repeated for the resulting matrix and if the aggregated matrix is consistent, priorities are computed using the normalized geometric mean method (see, (5)) (Franek, Kresta, 2014).

where: $\omega_{j}$ - weight of $j$ alternative.

$$
\omega_{j}=\frac{\sqrt[i]{\prod_{j=1}^{i} a_{i j}^{A}}}{\sum_{j=1}^{i} \sqrt[i]{\prod_{j=1}^{i} a_{i j}^{A}}}
$$

What is more, experts' consensus index, which was offered by Goepel (2013) is calculated. AHP consensus index compares experts' numerical estimations of criteria. The results vary from zero to 100 percent and show the level of agreement between the experts. Consensus index is calculated using the formula presented below (see (7)) (Goepel, 2013).

where: $S^{*}-$ consensus index,

$$
S^{*}=\frac{1 / \exp \left(H_{\beta}\right)^{-\exp \left(H_{\alpha \min }\right)} / \exp \left(H_{\gamma \max }\right)}{1^{-} \exp \left(H_{\alpha \min }\right) / \exp \left(H_{\gamma \max }\right)}
$$

$H_{\alpha}$ - Shannon alpha diversity,

$H_{\beta}$ - Shannon beta diversity,

$H_{\gamma}-$ Shannon gamma diversity.

\subsection{Fuzzy analytic hierarchy process}

Many scientist analyse Saaty's proposed pairwise comparison AHP method. Along with the AHP method, scientists analyse nine-point scale that is used for carrying out the comparison procedure. As a result, there are scientists who started claiming that nine-point scale does not fit expert evaluation procedure. Therefore, scale based on fuzzy logic was proposed (van Laarhoven, Pedrycz, 1983). Scientists suggested using triangle fuzzy numbers (van Laarhoven, Pedrycz, 1983). 
AHP method based on fuzzy numbers (Fuzzy AHP, FAHP) was created to reduce uncertainty while calculating factors' weights (Ishizaka, Nguyen, 2013). In fact, respondents' linguistic assessments of the same factor could differ due to human nature and character, hence, it is necessary to take uncertainty into consideration to make a less risky decision (Sehra et al., 2012). In other words, using fuzzy AHP increases calculations' accuracy (Vinogradova, 2012).

In the present research, triangle fuzzy numbers were based on numerical assessment provided for experts' evaluations. Actually, triangular fuzzy numbers are commonly used to find an appropriate solution to practical problems. Triangle fuzzy number $\tilde{A}$ is represented by $(l, m, u)$, and the membership function is defined by equation (8) (Beşikçi et al., 2016).

with $-\infty<l \leq m \leq u<+\infty$;

$$
\mu_{\tilde{A}}(x)=\left\{\begin{array}{c}
\frac{x-l}{m-l}, x \in[l ; m] \\
\frac{u-x}{u-m}, x \in[m ; u] \\
0, \quad x \notin[l ; u]
\end{array}\right.
$$

where: $\mu_{\tilde{A}}(x)$ - triangle-shaped membership function,

$m$ - the best estimate (the most probable value),

$l$ - the lowest estimate,

$u$ - the highest estimate.

The essence of FAHP method is that experts compare all the factors to each other. The assessment of experts ${ }^{6}$ opinion is carried out using triangular fuzzy-number scale, which is designed according to triangle-shaped membership function (see Table 3).

Table 3. Fuzzy Pairwise Comparison Scale

\begin{tabular}{|l|c|c|}
\hline Intensity of Importance of one criteria over another & Fuzzy number, $\tilde{a}_{i j}$ & Triangular fuzzy numbers \\
\hline Equal alternatives & $\tilde{1}$ & $(1,1,1)$ \\
\hline Equal importance & & $(1,1,2)$ \\
\hline Moderate importance & $\tilde{3}$ & $(2,3,4)$ \\
\hline Strong importance & $\tilde{5}$ & $(4,5,6)$ \\
\hline Very strong or demonstrated importance & $\tilde{7}$ & $(8,9,9,9)$ \\
\hline Extreme importance & $\tilde{9}$ & $(1,2,3),(3,4,5),(5,6,7),(7,8,9)$ \\
\hline Intermediate values & $\tilde{2}, \tilde{4}, \tilde{6}, \tilde{8}$ & \\
\hline
\end{tabular}

Source: Cobo et al. (2014)

Every expert has to make $n(n-1) / 2$ comparisons in order to design pairwise comparison matrix that is defined by the equation (9) (Cobo et al., 2014).

where: $m_{i j}=\frac{\sum_{t=1}^{T} a_{i j}^{t}}{T}$,

$$
\tilde{A}=\tilde{a}_{i j}=\left(l_{i j}, m_{i j}, u_{i j}\right) \text {, }
$$

$l_{i j}=\min _{t} a_{i j}^{t}$

$u_{i j}=\max _{t} a_{i j}^{t}$,

$T$ - number of experts,

$t=1,2, \ldots T$,

$\tilde{a}_{j i}=\frac{1}{\tilde{a}_{i j}}, \forall i, j=1,2, \ldots, n$. 
For experts' pairwise comparison matrices that satisfy the consistency condition $(\mathrm{CR}<0,2)$, the aggregated experts' assessment is calculated using a formula that is based on geometric mean (see (10)) (Lju, 2014).

$$
\tilde{a}_{i j}^{A}=\left(\tilde{a}_{i 1} \otimes \tilde{a}_{i 2} \otimes \ldots \otimes \tilde{a}_{i n}\right)^{1 / n},
$$

where: $\tilde{a}_{i j}^{A}$ - assessment of aggregated element that belongs to $i$ row and $j$ column.

$n$ - number of pairwise comparison matrices composed by one expert.

After aggregated experts' assessments are calculated the fuzzy weights of the criteria are computed (see (11)) (Lju, 2014).

$$
\widetilde{w}_{i}=\tilde{a}_{i j}^{A} \otimes\left(\tilde{a}_{i 1}^{A} \oplus \tilde{a}_{i 2}^{A} \oplus \ldots \oplus \tilde{a}_{i n}^{A}\right)^{-1}
$$

where: $\widetilde{w}_{i}=\left(L w_{i}, M w_{i}, U w_{i}\right)-$ fuzzy weight of $i$ alternative,

$M w i$ - the best fuzzy estimate (the most probable value),

$L w i$ - the lowest fuzzy estimate,

$U w i$ - the highest fuzzy estimate.

After fuzzy weights of each criterion is calculated, the most important factor is identified.

\section{Empirical Findings}

In order to get reliable research results the following requirements were set for the experts: 1) to have work or research experience in the banking sector; 2) to have at least a Master's degree in one of the following study areas: finance, economics, econometrics, management or business administration. In order to conduct the survey, three groups of experts (i.e. a group from each Baltic country) were selected based on non-probability sample. There were five experts in each group. Three forms of banking were analysed: traditional banking, internet banking and mobile banking in the current research. Experts had to rate the factors of CAMELS+T model to determine the level of the importance of each factor of the offered model in order to examine their influence on soundness of banks. The following results were obtained with 75 percent reliability.

Analysing experts' individual comparison matrices in the context of traditional banking, it was found that the use of classical AHP scale matrices, constructed by experts, coded $\mathrm{EC}+\mathrm{T}_{\mathrm{LT} 3}, \mathrm{EC}+\mathrm{T}_{\mathrm{LV} 2}, \mathrm{EC}+\mathrm{T}_{\mathrm{EE} 1,2,5}$, appeared to be inconsistent, while using AHP balanced scale only two matrices, created by experts, coded $\mathrm{EC}+\mathrm{T}_{\mathrm{LT} 3}, \mathrm{EC}+\mathrm{T}_{\mathrm{LV} 2}$, needed to be modified. Hence, before continuing computations, matrices were modified into consistent ones. Additionally, fuzzy numbers were used for the purpose of CAMELS+T model testing. The results of the CAMELS+T factors where " $T$ " stands for "trust in traditional banking" assessments are given below (see Table 4). Consistency ratio and lambda $(\lambda)$ meet the given conditions (see Table 4); consequently, experts' aggregated assessments could be used for obtaining general results.

\begin{tabular}{|c|c|c|c|c|c|c|c|c|c|}
\hline \multicolumn{10}{|c|}{ Normalized eigenvector } \\
\hline Country & \multicolumn{3}{|l|}{ LT } & \multicolumn{3}{|l|}{ LV } & \multicolumn{3}{|l|}{$\mathrm{EE}$} \\
\hline Method & \multicolumn{2}{|l|}{ AHP } & \multirow{2}{*}{ FAHP } & \multicolumn{2}{|l|}{ AHP } & \multirow{2}{*}{ FAHP } & \multicolumn{2}{|l|}{ AHP } & \multirow{2}{*}{ FAHP } \\
\hline Scale & Class. & Balan. & & Class. & Balan. & & Class. & Balan. & \\
\hline $\mathrm{C}$ & 0,071 & 0,079 & 0,000 & 0,104 & 0,108 & 0,059 & 0,081 & 0,106 & 0,017 \\
\hline $\mathrm{A}$ & 0,136 & 0,138 & 0,120 & 0,088 & 0,110 & 0,043 & 0,121 & 0,142 & 0,123 \\
\hline
\end{tabular}

Table 4. Weights of the CAMELS+T model's factors in the context of traditional banking 
The International Journal

ENTREPRENEURSHIP AND SUSTAINABILITY ISSUES

ISSN 2345-0282 (online) http://jssidoi.org/jesi/ 2016 Volume 4 Number 2 (December)

\begin{tabular}{|l|l|l|l|l|l|l|l|l|l|}
\hline $\mathrm{M}$ & 0,154 & 0,163 & 0,194 & 0,151 & 0,145 & 0,200 & 0,200 & 0,181 & 0,255 \\
\hline $\mathrm{E}$ & 0,063 & 0,085 & 0,000 & 0,126 & 0,118 & 0,077 & 0,128 & 0,141 & 0,100 \\
\hline $\mathrm{L}$ & 0,173 & 0,160 & 0,241 & 0,187 & 0,181 & 0,261 & 0,239 & 0,196 & 0,285 \\
\hline $\mathrm{S}$ & 0,123 & 0,132 & 0,028 & 0,114 & 0,132 & 0,098 & 0,046 & 0,075 & 0,000 \\
\hline $\mathrm{T}$ & 0,280 & 0,243 & 0,417 & 0,229 & 0,206 & 0,262 & 0,184 & 0,159 & 0,220 \\
\hline \multicolumn{8}{|c|}{ Parameters } \\
\hline$\lambda$ & 7,171 & 7,109 & 7,171 & 7,178 & 7,086 & 7,178 & 7,133 & 7,137 & 7,133 \\
\hline CR & 0,021 & 0,014 & 0,021 & 0,022 & 0,011 & 0,022 & 0,016 & 0,017 & 0,016 \\
\hline Cons., $\%$ & 59,6 & 79,7 & 59,6 & 42,6 & 66,1 & 42,6 & 63,4 & 86,1 & 63,4 \\
\hline
\end{tabular}

Source: authors' calculations

As shown in Table 4, Latvian and Lithuanian experts ranked trust in the highest position in bank's soundness building process. In fact, clients' trust in traditional banking is more significant than the other criterion's weights and exceeds 20 percent limit. Thus, it can be concluded that trust in traditional banking system is necessary to ensure soundness of commercial banks. Lithuanian experts assessed capital adequacy and bank's earnings as factors that overall have no impact on banks' soundness. These results can be explained by the fact that every bank has a license, ensuring a minimum level of capital adequacy. That is to say, if the level is higher than the mandatory minimum, it does not affect banks' soundness. Estonian experts have marked liquidity as a key factor having impact on banks' soundness and trust was ranked at third position. Analysing Estonian experts' assigned weights for examined factors, it can be seen, that there are no outliers which means that differences between the weights of the factors are not so essential, compared to Lithuanian and Latvian experts. Actually, the only factor that stands out in the case of Estonia is the sensitivity to market risk that was evaluated as having the lowest weight in banks' soundness building process. Moreover, according to Estonian experts, sensitivity to market risk is equal to zero, if assessed with FAHP method. This is to say, there is no relationship between sensitivity to market risk and commercial banks' soundness.

In online banking, the effects of trust on soundness have also been examined, using the expert evaluation method. Investigating the pairwise comparison of CAMELS+T criteria by experts in Baltic countries matrices showed that $\mathrm{EC}+\mathrm{T}_{\mathrm{LT} 3}, \mathrm{EC}+\mathrm{T}_{\mathrm{LV} 3}, \mathrm{EC}+\mathrm{T}_{\mathrm{EE} 2,5}$ matrices in classical scaling and $\mathrm{EC}+\mathrm{T}_{\mathrm{LT} 3}, \mathrm{EC}+\mathrm{T}_{\mathrm{LV} 3}$ matrices in balanced scaling were inconsistent. Therefore, before aggregating global results, mentioned matrices were modified, according to method-S, presented in the methodology part. Triangles, fuzzy numbers were also used for results generation as experts' evaluations are often uncertain. The weights of CAMELS+T model factors throughout investigation process of trust in internet banking are presented in Table 5. Consistency ratio and lambda $(\lambda)$ meet the given conditions (see Table 5) and indicate that the aggregated experts' evaluations may be used for obtaining general results. The weights of CAMELS+T model factors throughout investigation process of trust in internet banking are presented in Table 5.

Table 5. Weights of the CAMELS+T Model's Factors in the Context of Internet Banking

\begin{tabular}{|c|c|c|c|c|c|c|c|c|c|}
\hline \multicolumn{10}{|c|}{ Normalized eigenvector } \\
\hline Country & \multicolumn{3}{|c|}{ LT } & \multicolumn{3}{|c|}{ LV } & \multicolumn{3}{|c|}{$\mathrm{EE}$} \\
\hline Method & \multicolumn{2}{|c|}{ AHP } & \multirow{2}{*}{ FAHP } & \multicolumn{2}{|c|}{ AHP } & \multirow{2}{*}{ FAHP } & \multicolumn{2}{|c|}{ AHP } & \multirow{2}{*}{ FAHP } \\
\hline Scale & Class. & Balan. & & Class. & Balan. & & Class. & Balan. & \\
\hline $\mathrm{C}$ & 0,071 & 0,079 & 0,022 & 0,065 & 0,082 & 0,017 & 0,080 & 0,108 & 0,055 \\
\hline A & 0,100 & 0,121 & 0,021 & 0,083 & 0,092 & 0,000 & 0,101 & 0,128 & 0,099 \\
\hline $\mathrm{M}$ & 0,131 & 0,135 & 0,112 & 0,143 & 0,154 & 0,248 & 0,179 & 0,171 & 0,203 \\
\hline E & 0,076 & 0,091 & 0,000 & 0,116 & 0,116 & 0,080 & 0,215 & 0,182 & 0,215 \\
\hline $\mathrm{L}$ & 0,198 & 0,191 & 0,285 & 0,105 & 0,121 & 0,253 & 0,169 & 0,169 & 0,202 \\
\hline$S$ & 0,128 & 0,150 & 0,094 & 0,096 & 0,124 & 0,079 & 0,041 & 0,074 & 0,000 \\
\hline
\end{tabular}


The International Journal

ENTREPRENEURSHIP AND SUSTAINABILITY ISSUES

ISSN 2345-0282 (online) http://jssidoi.org/jesi/ 2016 Volume 4 Number 2 (December)

\begin{tabular}{|c|c|c|c|c|c|c|c|c|c|}
\hline $\mathrm{T}$ & 0,196 & 0,234 & 0,466 & 0,392 & 0,312 & 0,324 & 0,214 & 0,168 & 0,225 \\
\hline \multicolumn{10}{|c|}{ Parameters } \\
\hline$\lambda$ & 7,124 & 7,090 & 7,124 & 7,121 & 7,122 & 7,121 & 7,252 & 7,130 & 7,252 \\
\hline CR & 0,015 & 0,011 & 0,015 & 0,015 & 0,015 & 0,015 & 0,031 & 0,016 & 0,031 \\
\hline Cons., \% & 61,6 & 77,4 & 61,6 & 58,1 & 74,7 & 58,1 & 64,3 & 86,5 & 64,3 \\
\hline
\end{tabular}

Source: authors' calculations

The examination of the weights of CAMELS+T factors, illustrated in Table 5, shows that Latvian and Lithuanian experts ranked trust to be in the first position in the context of internet banking. Moreover, the share of trust in internet banking reaches almost 20 percent, according to Lithuanian and Latvian experts. In fact, it shows that users' tendency to rely on online services provided by commercial banks, i.e. trust in internet banking, is the fundamental factor in building soundness of commercial banks' and supporting process. In fact, if people did not trust online banking, the usage of the service would decrease, which in turn would weaken banks' soundness.

Meanwhile, analysis of Estonian experts' answers demonstrate that trust assessment depends on the scale, used in the survey. Using classical scale experts set trust in the second position; using balanced scale - the fourth position; using fuzzy logic scale - the first position. In fact, investigation of other factors' weights illustrate that there is no significant difference between liquidity, earnings, management quality and trust weights, therefore, Estonian experts assess trust as the key factor in commercial banks soundness' development along with other factors.

Analysing the pairwise comparison matrices by experts in the Baltic States, assessing factors of CAMELS+T model, when " $T$ " stands for trust in mobile banking, inconsistent matrices were identified. They are coded as follows: $\mathrm{EC}+\mathrm{T}_{\mathrm{LT} 3}, \mathrm{EC}+\mathrm{T}_{\mathrm{LV} 3}, \mathrm{EC}+\mathrm{T}_{\mathrm{EE} 2,5}$ using classical scale and $\mathrm{EC}+\mathrm{T}_{\mathrm{LT} 3}, \mathrm{EC}+\mathrm{T}_{\mathrm{LV} 3}$ using balanced scale. After modification of matrices, CAMELS+T model was tested not only using AHP classical and balanced scales, but also triangles, fuzzy numbers. The weights of the examined factors are shown in Table 6.

Consistency ratio and lambda $(\lambda)$ meet the given conditions and indicate that the aggregated experts' evaluations may be used for obtaining general results.

Table 6. Weights of the CAMELS+T Model Factors in the Context of Mobile Banking

\begin{tabular}{|c|c|c|c|c|c|c|c|c|c|}
\hline \multicolumn{10}{|c|}{ Normalized eigenvector } \\
\hline Country & \multicolumn{3}{|c|}{ LT } & \multicolumn{3}{|c|}{$\mathrm{LV}$} & \multicolumn{3}{|c|}{$\mathrm{EE}$} \\
\hline Method & \multicolumn{2}{|c|}{ AHP } & \multirow{2}{*}{ FAHP } & \multicolumn{2}{|c|}{ AHP } & \multirow{2}{*}{ FAHP } & \multicolumn{2}{|c|}{ AHP } & \multirow{2}{*}{ FAHP } \\
\hline Scale & Class. & Bal. & & Class. & Bal. & & Class. & Bal. & \\
\hline $\mathrm{C}$ & 0,082 & 0,089 & 0,000 & 0,064 & 0,082 & 0,009 & 0,079 & 0,107 & 0,067 \\
\hline A & 0,070 & 0,087 & 0,000 & 0,077 & 0,092 & 0,000 & 0,092 & 0,126 & 0,072 \\
\hline $\mathrm{M}$ & 0,114 & 0,110 & 0,000 & 0,133 & 0,145 & 0,259 & 0,192 & 0,184 & 0,222 \\
\hline$E$ & 0,09311 & 0,111 & 0,000 & 0,118 & 0,115 & 0,071 & 0,214 & 0,178 & 0,226 \\
\hline $\mathrm{L}$ & 0,181 & 0,169 & 0,279 & 0,116 & 0,125 & 0,282 & 0,167 & 0,167 & 0,193 \\
\hline$S$ & 0,09313 & 0,117 & 0,000 & 0,094 & 0,122 & 0,040 & 0,042 & 0,073 & 0,000 \\
\hline $\mathrm{T}$ & 0,367 & 0,317 & 0,721 & 0,397 & 0,320 & 0,340 & 0,213 & 0,165 & 0,220 \\
\hline \multicolumn{10}{|c|}{ Parameters } \\
\hline$\lambda$ & 7,165 & 7,086 & 7,165 & 7,125 & 7,103 & 7,125 & 7,243 & 7,121 & 7,243 \\
\hline $\mathrm{CR}$ & 0,020 & 0,011 & 0,020 & 0,016 & 0,013 & 0,016 & 0,030 & 0,015 & 0,030 \\
\hline Cons., $\%$ & 60,2 & 68,9 & 60,2 & 59,4 & 75,9 & 59,4 & 73,2 & 88,7 & 73,2 \\
\hline
\end{tabular}

Source: authors' compilations 
The results, presented in Table 6, are similar to the results, generated while testing CAMELS+T model in traditional banking and trust in internet banking. An obvious example is Lithuanian and Latvian experts' opinions showing that consumer trust in mobile banking is the vital factor, ensuring soundness of commercial banks. This could be explained by the fact that mobile banking is a relatively new service, and people tend not to rely on new services, due to the lack of experience using it. Thus, it is necessary to build clients' trust in mobile banking as it might ensure common usage and further development of mobile banking service. Meanwhile, Estonian experts ranked trust in mobile banking to be in the second and the fourth positions, assessing by classic and balanced scales respectively. Obviously, according to Estonian experts trust in mobile banking is not the most important factor to ensure commercial banks' soundness. Nevertheless, the weight of trust should not be underestimated, according to the survey, conducted in Estonia; in this case, the weights of all the factors are distributed evenly which means there are no extreme outliers. In other words, Estonian experts claimed that a high level of commercial banks' soundness could be reached if all the factors of CAMELS+T models work together. It could be explained by the fact, that Estonian residents' level of trust in mobile banking is higher than in the neighbouring Baltic countries, therefore, Estonians pay attention not only to trust in mobile banking, but also to other factors of banks' soundness. Regarding the weights of factors, calculated based on fuzzy logic method, it could be seen that there are factors that do not have impact on banks' soundness. In Lithuania, these factors include capital adequacy, asset quality, management quality, profit, and sensitivity to the market risk, in Latvia - asset quality, in Estonia - sensitivity to market risk. Such results could be explained by the fact that users of mobile banking equate the service not only with the bank whose services they use, but also with the mobile operator, they use.

\section{Conclusions}

The study analyses the importance of customer trust for development of banks' soundness. In consistency with the main objective of the article, banks' soundness assessment model CAMELS was modified into CAMELS+T, adding the „T" which stands for customer trust in commercial banks. In turn, trust was investigated in three forms as follows: trust in traditional banking, trust in internet banking, and trust in mobile banking. The proposed theoretical CAMELS+T model was tested empirically, using expert evaluation method as expertise was needed to understand questions properly. The research was conducted in Latvia, Lithuania and Estonia. Five experts from each country participated in the research. Experts had to rate the factors to determine the level of the importance of each factor of the offered model. Pairwise comparison method was used for ranking. The outcomes of the experts' pairwise comparison were generated using analytic hierarchy process based on classical and balanced scales and fuzzy analytic hierarchy process technique.

The results show that it is necessary to increase the level of customer trust in commercial banks, as it is one of the vital elements of soundness of banks. The research results show that the evidence supported the hypothesis and the theoretical CAMELS+T model could be used practically. The level of reliability of the results exceeds 75 percent threshold. According to the research results, trust in traditional banking is considered the most important factor in CAMELS+T soundness building model in Lithuania and Latvia. Estonian experts gave the third position for trust in traditional banking. Investigating weights of CAMELS+T factors in banks' soundness improvement in internet banking, Lithuanian and Latvian experts identified trust as the most important factor in banks" soundness, whereas, Estonian experts ranked trust in the second, the fourth and the first positions in internet banking, using AHP classical and balanced scales and FAHP techniques respectively. However, there is a slight difference in weights between trust in internet banking and other CAMELS+T factors. This is to say, trust in internet banking is almost as essential as other factors of models in banks' soundness building process. Lithuanian and Latvian experts set trust in the first position while examining the impact of trust in mobile banking on banks' soundness level. Estonian experts considered trust in mobile banking as one of the vital factors influencing high banks' soundness level, but they do not diminish the significance of other factors. In fact, trust in mobile banking was set in the second, fourth and third position, using AHP classical and balanced scales and FAHP techniques, respectively. Actually, the difference 
between the most and the least essential weights of factors is quite insignificant, hence, it could be said that all factors of CAMELS+T model are almost equal in building banks' soundness. According to the research findings, the high level of banks' soundness could be reached through raise of the level of customer trust in traditional, internet and mobile banking which means that the theoretical CAMELS+T model was confirmed to be suitable for building the soundness of commercial banks. The overall conclusion seems to be that, customer trust is a crucial factor since customer trust strongly influences their choice of a commercial bank. In other words, the findings suggest modifying the CAMELS soundness model to CAMELS+T, where "T" stands for customer trust. Actually, the research results contribute to the science in the field of commercial banks' soundness assessment by suggesting theoretical CAMELS+T model which is prepared to be tested in practice in different countries' banking markets.

In order to understand fully customer trust's role in increasing banks' soundness level further researches need to be conducted. A similar one is advisable in Nordic countries, as quite large section of banks, operating in the Baltics, are of Nordic origin. The results of such analysis would permit to use CAMELS+T model, instead of using CAMELS, assessing commercial banks' soundness not only in Nordic and Baltic countries, but in other markets as well.

\section{References}

Al-Khouri, R.; Arouri, H. (2016). The simultaneous estimation of credit growth , valuation , and stability of the Gulf Cooperation Council banking industry. Economic Systems. http://doi.org/10.1016/j.ecosys.2015.12.005

Beşikçi, E. B.; Kececi, T.; Arslan, O.; Turan, O. (2016). An application of fuzzy-AHP to ship operational energy efficiency measures. Ocean Engineering, 121, 392-402. http://doi.org/10.1016/j.oceaneng.2016.05.031

Carretta, A.; Farina, V.; Fiordelisi, F.; Schwizer, P.; Stentella Lopes, F. S. (2015). Don't Stand So Close to Me: The role of supervisory style in banking stability. Journal of Banking and Finance, 52, 180-188. http://doi.org/10.1016/j.jbankfin.2014.09.015

Cobo, A.; Vanti, A. A.; Rocha, R. (2014). A Fuzzy Multicriteria Approach for it Governance Evaluation. Journal of Information Systems and Technology Management: JISTEM, 112(2), 257-276. http://doi.org/10.4301/S1807-17752014000200003

Davoodi, A. (2009). On Inconsistency of a Pairwise Comparison Matrix. International Journal of Industrial Mathematics, 1(4), 343-350. Retrieved from http://ijim.srbiau.ac.ir/volume_437.html

Dima, B.; Dincă, M. S.; Spulbăr, C. (2014). Financial nexus: Efficiency and soundness in banking and capital markets. Journal of International Money and Finance, 47, 100-124. http://doi.org/10.1016/j.jimonfin.2014.05.002

Dubauskas, G. (2012). Sustainable growth of the financial sector: the case of credit unions, Journal of Security and Sustainability Issues 1(3): 159-166. http://dx.doi.org/10.9770/jssi/2012.1.3(1)

Fernández, A. I.; González, F.; Suárez, N. (2016). Banking stability, competition, and economic volatility. Journal of Financial Stability, 22, 101-120. http://doi.org/10.1016/j.jfs.2016.01.005

Franek, J.; Kresta, A. (2014). Judgment Scales and Consistency Measure in AHP. Procedia Economics and Finance, 12(March), 164-173. http://doi.org/10.1016/S2212-5671(14)00332-3

Fungáčová, Z.; Hasan, I. (2016). Trust in banks Institute for Economies in Transition. Retrieved from http://www.suomenpankki.fi/bofit/tutkimus/tutkimusjulkaisut/dp/Documents/2016/dp0716.pdf

Fuschi, D.; Tvaronavičienè, M. (2014). Sustainable development, Big Data and supervisory control: service quality in banking sector, Journal of Security and Sustainability Issues 3(3): 5-14. http://dx.doi.org/10.9770/jssi.2014.3.3(1)

Gao, Y.; Liao, S.; Wang, X. (2016). Capital Markets' Assessment of the Economic Impact of the Dodd-Frank Act on Systemically Important Financial Firms. Journal of Banking \& Finance. http://doi.org/10.1016/j.jbankfin.2016.03.016

Garškaitè-Milvydienè, K. (2012). Diagnostics of bankruptcy threat to enterprises, Journal of Security and Sustainability Issues 1(3): 197203. http://dx.doi.org/10.9770/jssi/2012.1.3(5) 
Ginevicius, R.; \& Podviezko, a. (2013). The Evaluation of Financial Stability and Soundness of Lithuanian Banks. Ekonomska IstrazivanjaEconomic Research, 26(2), 191-207. http://dx.doi.org/10.1080/1331677X.2013.11517616

Goepel, K. D. (2013). Implementing the Analytic Hierarchy Process as a Standard Method for Multi-Criteria Decision Making In Corporate Enterprises - A New AHP Excel Template with Multiple Inputs. Proceedings of the International Symposium on the Analytic Hierarchy Process, 1-10. Retrieved from http://bpmsg.com/wp-content/uploads/2013/06/ISAHP_2013-13.03.13.Goepel.pdf

Ishizaka, A.; Labib, A. (2011). Review of the main developments in the analytic hierarchy process. Expert Systems with Applications, 38(11), 14336-14345. http://doi.org/10.1016/j.eswa.2011.04.143

Kalyugina, S.; Strielkowski, W.; Ushvitsky, L.; Astachova, E. (2015). Sustainable and secure development: facet of personal financial issues, Journal of Security and Sustainability Issues 5(2): 297-304. http://dx.doi.org/10.9770/jssi.2015.5.2(14)

Karanovic, G.; Karanovic, B. (2015). Developing an Aggregate Index for Measuring Financial Stability in the Balkans. Procedia Economics and Finance, 33(15), 3-17. http://doi.org/10.1016/S2212-5671(15)01690-1

Kaźmierczyk, J. (2012). Information technology systems and their impact on the employment level in the polish banking sector, Journal of Security and Sustainability Issues 1(3): 187-195. http://dx.doi.org/10.9770/jssi/2012.1.3(4)

Korauš, A.; Dobrovič, J.; Ključnikov, A.; Gombár, M. (2016). Consumer approach to bank payment card security and fraud, Journal of Security and Sustainability Issues 6(1): 85-102. http://dx.doi.org/10.9770/jssi.2016.6.1(6)

Lankauskienè, T.; Tvaronavičienè, M. (2012). Security and sustainable development approaches and dimensions in the globalization context, Journal of Security and Sustainability Issues 1(4): 287-297. http://dx.doi.org/10.9770/jssi.2012.1.4(5)

Libby, R.; Blashfield, R. K. (1978). Performance of a composite as a function of the number of judges. Organizational Behavior and Human Performance, 21(2), 121-129. http://doi.org/10.1016/0030-5073(78)90044-2

Lui, A. (2013). Macro and micro prudential regulatory failures between banks in the United Kingdom and Australia 2004-2009. Journal of Financial Regulation and Compliance, 21(3), 241-258. http://doi.org/10.1108/JFRC-10-2012-0044

Menicucci, E.; Paolucci, G. (2016). The determinants of bank profitability: empirical evidence from European banking sector. Journal of Financial Reporting and Accounting, 14(1), 86-115. http://doi.org/10.1108/JFRA-05-2015-0060

Minto, A. (2016). The spirit of the law over its letter: the role of culture and social norms in shielding cooperative banks from systemic shocks. Law and Financial Markets Review, 10(1), 16-26. http://doi.org/10.1080/17521440.2016.1154298

Motelle, S. I.; Biekpe, N. (2014). Financial intermediation spread and stability of the banking system in the Southern Africa Customs Union. Managerial Finance, 40(3), 276-299. http://doi.org/10.1108/MF-06-2013-0147

Nicolaci, D. C. (2014). Fed's Dudley Sees Loss of Trust in Banks as Threat to Stability. Retrieved August 3, 2016, from http://on.wsj.com/1F8gc5U

Obata, T.; Shiraishi, S.; Daigo, M.; Nakajima, N. (1999). Assessment for an Incomplete Comparison Matrix and Improvement of an Inconsistent Comparison: Computational experiments. International Journal of the Analytic Hierarchy Process, 0-5. Retrieved from http://www3.u-toyama.ac.jp/shira/isahp.pdf

Park, J. (2012). Corruption, soundness of the banking sector, and economic growth: A cross-country study. Journal of International Money and Finance, 31(5), 907-929. http://doi.org/10.1016/j.jimonfin.2011.07.007

Podviezko, A.; Ginevičius, R. (2010). Economic criteria characterising bank soundness and stability. The 6th International Scientific Conference "Business and Management 2010”. Selected Papers, 1072-1079. http://doi.org/10.3846/bm.2010.144

Saaty, T. L. (1988). The analytic hierarchy process : planning, priority setting, resource allocation (2nd ed.). Pittshburg: University of Pittsburgh.

Saaty, T. L. (2012). Decision Making for Leaders: the analytic hierarchy process for decisions in a complex world (3rd ed.). Pittshburg: RWS Publications. 
The International Journal

ENTREPRENEURSHIP AND SUSTAINABILITY ISSUES

ISSN 2345-0282 (online) http://jssidoi.org/jesi/

2016 Volume 4 Number 2 (December)

Salo, A. A.; Hämäläinen, R. P. (1997). On the measurement of preferences in the analytic hierarchy process. Journal of Multi-Criteria Decision Analysis, 6(November 1994), 309-319. http://doi.org/10.1002/(SICI)1099-1360(199711)6:6<309::AIDMCDA163>3.0.CO;2-2

Sehra, S. K.; Brar, Y. S.; Kaur, N. (2012). Multi Criteria Decision Making Approach for Selecting Effort Estimation Model. International Journal of Computer Applications, 39(1), 10-17. Retrieved from https://arxiv.org/ftp/arxiv/papers/1310/1310.5220.pdf

Stasytytė, V. (2015). Conceptualization of financial system sustainability, Journal of Security and Sustainability Issues 4(4): 391402. http://dx.doi.org/10.9770/jssi.2015.4.4(6)

Tamulevičienė, D. (2016). Methodology of complex analysis of companies' profitability, Entrepreneurship and Sustainability Issues 4(1): 53-63. http://dx.doi.org/10.9770/jesi.2016.4.1(5)

Van Laarhoven, P. J. M.; Pedrycz, W. (1983). A fuzzy extension of Saaty's priority theory. Fuzzy Sets and Systems, 11(1-3), 229-241. http://doi.org/10.1016/S0165-0114(83)80082-7

Vinogradova, I. (2012). Neapibrezžtumo įtaka AHP metodo vertinimams [Uncertainty influence on evaluation based on AHP method] Lietuvos Matematikos Rinkinys, 53, 243-248.

Warjiyo, P. (2016). Central bank policy mix: key concepts and Indonesia's experience. Buletin Ekonomi Moneter Dan Perbankan, 18(4), 379-408. http://dx.doi.org/10.21098/bemp.v18i4.573

Zolfani, S. H.; Antucheviciene, J. (2012). Team member selecting based on AHP and TOPSIS grey. Engineering Economics, 23(4), 425434. http://doi.org/10.5755/j01.ee.23.4.2725

Aksenov, V. V, Blaschuk, M. Y., Chernuhin, R. V. [Аксёнов, В. В.; Блащук, М. Ю.; Чернухин, Р. В.] (2014). Применение метода анализа иерархий для выбора типа насоса энергосиловой установки геохода [Application of the analytic hierarchy process at a choice of pumps of the energy-power block of a geokhod]. Вестник Кузбасского Государственного Технического Университета, 3(103), 38-42. Retrieved from http://cyberleninka.ru/article/n/primenenie-metoda-analiza-ierarhiy-dlya-vybora-tipa-nasosa-energosilovoyustanovki-geohoda

Kostin, L.V. [Костин, Л. В.] (2014). Использование метода анализа иерархий в процессе оценки потенциала клиентов рынка логистических услуг [Use of hierarchy analysis method in estimating of logistics market clients' potential]. Экономика И Управление, 3(39), 86-90. Retrieved from http://elibrary.miu.by/journals!/item.eiup/issue.39/article.18.pdf

Lju, X. [Лю, X.] (2014). Метод нечеткого анализа иерархий для выбора сайта электронной коммерции [Fuzzy hierarchy analysis method for choosing an e-commerce website]. Вестник БГУ, 1(3), 89-93. Retrieved from http://elib.bsu.by/handle/123456789/118695

Sokolova, V.I.; Tishina, V.N. [Соколова, В. И., \& Тишина, В. Н.] (2015). Взаимосвязь между устойчивостью банковской системы и уровнем доверия потребителей [Impact of Banks' Soundness on Customer Trust Index]. Young Scientist, 6(86), 461-465. Retrieved from http://moluch.ru/archive/86/16354/

Daiva JUREVIČIENE் - Doctor of Social Sciences, professor; Department of Financial Engineering, Faculty of Business Management, Vilnius Gediminas Technical University. Research interests: banking, risk management, investments, personal finances, individual financial behaviour.

ORCID ID: orcid.org/0000-0002-0039-6290

Viktorija SKVARCIANY

ORCID ID: orcid.org/0000-0001-8022-4124; RESEARCHER ID: P-7584-2016 
The International Journal

ENTREPRENEURSHIP AND SUSTAINABILITY ISSUES

ISSN 2345-0282 (online) http://jssidoi.org/jesi/

2016 Volume 4 Number 2 (December)

Copyright (C) 2016 by author(s) and VsI Entrepreneurship and Sustainability Center

This work is licensed under the Creative Commons Attribution International License (CC BY).

http://creativecommons.org/licenses/by/4.0/

(c) (i) Open Access 